electroconvulsive therapy (ECT) and simulated ECT in depressive illness. Lancet 1978 ; i :738-40.

${ }^{3}$ Johnstone EC, Deakin JFW, Lawler P, et al. The Northwick Park electroconvulsive therapy trial. Lancet 1980 ;ii:1317-20.

4 Lambourn J, Gill D. A controlled comparison of simulated and real ECT. Br f Psychiatry 1978;133:514-9.

${ }^{5}$ Feighner JP, Robins E, Guze S, Woodruff R, Winokur G, Munoz R. Diagnostic criteria for use in psychiatric research. Arch Gen Psychiatry $1972 ; 26: 57-63$.

${ }^{6}$ Beck AT, Ward CH, Mendelson M, Mock J, Erbaugh J. An inventory for measuring depression. Arch Gen Psychiatry 1961 ;4:561-71.

7 Imlah NW, Ryan E, Harrington JA. The influence of antidepressant drugs in the response to electroconvulsive therapy and on subsequent relapse rates. Fournal of Neuropsychopharmacology 1965;4:439-42.
${ }^{8}$ Kay D, Fahy T, Garside R. A seven-month double-blind trial of amitriptyline and diazepam in ECT treated depressed patients. Brf P Pychiatry $1970 ; 117: 667-71$.

${ }^{9}$ Mindham RHS, Howland C, Sheppard M. An evaluation of continuation therapy with tricyclic antidepressants in depressive illness. Psychol Med $1973 ; 3: 5-17$.

${ }^{10}$ Coppen A, Ghose K, Montgomery S, Rao VAR, Bailey J, Jørgensen A. Continuation therapy with amitriptyline in depression. $\mathrm{Br} \mathcal{F}$ Psychiatry $1978 ; 133: 28-33$.

11 Perry A, Tsuang MT. Treatment of unipolar depression following electroconvulsive therapy. Fournal of Affective Disorders 1979;1:123-9.

${ }^{12}$ Coppen A, Noguera R, Bailey J, et al. Prophylactic lithium in affective disorders. Lancet 1971 ;ii :275-9.

(Accepted 5 December 1980)

\title{
Policy for prevention of Asian rickets in Britain: a preliminary assessment of the Glasgow rickets campaign
}

\author{
M G DUNNIGAN, W B McINTOSH， G R SUTHERLAND， R GARDEE， B GLEKIN, J A FORD, \\ I ROBERTSON
}

\begin{abstract}
Evidence of continuing hospital admissions of patients with Asian rickets and osteomalacia led to a further attempt to provide more effective preventive measures for the Glasgow Asian community. Dose-response studies showed that the equivalent of $10 \mu \mathrm{g}$ of vitamin D daily would provide effective prophylaxis, and a general practice survey showed that self-administered vitamin $D$ supplements would reduce the prevalence and severity of Asian rickets. A multidisciplinary working group devised a preventive campaign based on the free issue of vitamin D supplements on demand to children who required them. Supported by a health education programme for community health personnel and the Asian community, the first 16 months of the campaign produced an eightfold rise in the issue of supplements to older Asian children and a $33 \%$ increase in their issue to infants of all ethnic groups.

Because more children are receiving vitamin $D$ supplementation the campaign seems likely to reduce the prevalence of Asian rickets in Glasgow.
\end{abstract}

\section{Introduction}

Rickets and osteomalacia remain common among Asians in Britain, ${ }^{1-4}$ but prophylactic measures have been poorly organised

Departments of Medicine, Biochemistry, and Radiology, Stobhill General Hospital, Glasgow G21 3UW

M G DUNNIGAN, MD, FRCP, consultant physician

W B MCINTOSH, FIMLS, senior chief medical laboratory scientific officer

G R SUTHERLAND, FRCP, FRCR, consultant radiologist

Greater Glasgow Health Board, Glasgow G2 3HT

R GARDEE, MFCM, DPH, senior registrar in community medicine

Woodside Health Centre, Glasgow G20 7LR

B GLEKIN, MB, CHB, general practitioner

Paediatric Unit, Rutherglen Maternity Hospital, Rutherglen J A FORD, MB, MRCP, consultant paediatrician

Department of Mathematics, University of Strathclyde, Glasgow G1 I ROBERTSON, BSC, DIPSTAT, lecturer and no account of an effective preventive campaign has been published. We describe the encouraging results of a campaign initiated by the Greater Glasgow Health Board in March 1979.

\section{Population data}

PATIENTS DISCHARGED FROM HOSPITAL WITH NUTRITIONAL RICKETS AND OSTEOMALACIA

Altogether 138 Asians were discharged from Glasgow hospitals with a diagnosis of nutritional rickets or osteomalacia during 1968-78 (table I, fig 1). The Asian population of the city is estimated to have increased from about 8000 to 14000 in this time. The annual incidence

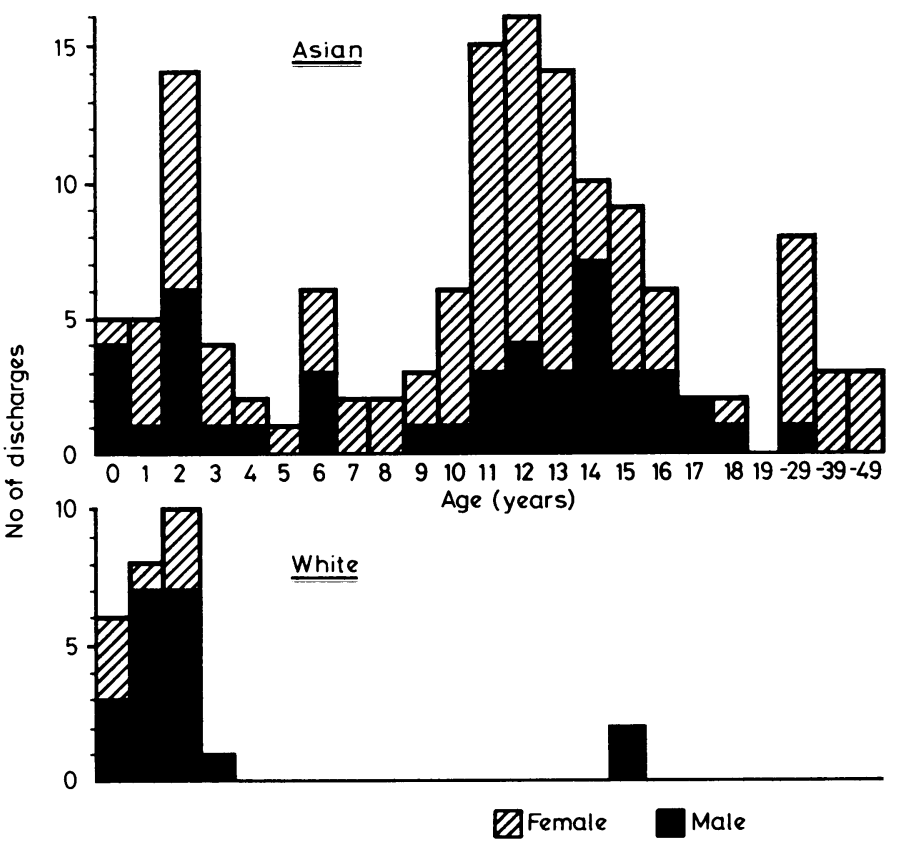

FIG 1-Numbers of white and Asian patients discharged from all Glasgow hospitals with nutritional rickets and osteomalacia between 1968 and 1978 . Each case record was examined. 
of rickets among Asian schoolchildren showed significant changes between 1969 and 1970, 1970 and 1971, and 1974 and $1975(z=3.56$, 2.30 , and 4.09 respectively, $\mathrm{p}<0.05$ ), but no consistent trend was evident. Over this period an Asian child aged 5 years was estimated to have a probability of 1 in $29(3.5 \%)$ of being admitted to hospital during school life up to 16 years.

The number of cases of infantile rickets in the white population was small; two adolescents had biochemical evidence of rickets but no evidence on radiography. children from a general practice whose population was drawn from the area served by the clinic. A blood sample was taken for biochemical screening from 189 children, and those in whom the results were abnormal were recalled for radiography of both knees. Radiographs were reported in the absence of clinical and laboratory data and classified as abnormal, borderline, or normal. For the purpose of this study only the abnormal films were classified as rachitic. The stated pattern of supplement taking was noted at first interview and classified as regular ( 57 children, mean age $11 \cdot 2$ years), intermittent ( 53 children,

TABLE I-Numbers of white and Asian patients with nutritional rickets and osteomalacia discharged from all Glasgow hospitals 1968-78

\begin{tabular}{|c|c|c|c|c|c|c|c|}
\hline \multirow{2}{*}{ Year } & \multicolumn{2}{|c|}{$0-4$ years } & \multicolumn{2}{|c|}{$17-49$ years } & \multicolumn{2}{|c|}{$5-16$ years } & \multirow{2}{*}{$\begin{array}{c}\text { Incidence* } \\
\text { in Asians aged } \\
5-16 \\
\text { years }\end{array}$} \\
\hline & White & Asian & White & Asian & White & Asian & \\
\hline $\begin{array}{l}1968 \\
1969 \\
1970 \\
1971 \\
1972 \\
1973 \\
1974 \\
1975 \\
1976 \\
1977 \\
1978\end{array}$ & $\begin{array}{l}7 \\
4 \\
1 \\
3 \\
5 \\
1 \\
3 \\
1 \\
0 \\
0 \\
0\end{array}$ & $\begin{array}{l}5 \\
2 \\
3 \\
4 \\
6 \\
3 \\
0 \\
1 \\
1 \\
2 \\
3\end{array}$ & $\begin{array}{l}0 \\
0 \\
0 \\
0 \\
0 \\
0 \\
0 \\
0 \\
0 \\
0 \\
0\end{array}$ & $\begin{array}{l}0 \\
0 \\
0 \\
0 \\
2 \\
2 \\
2 \\
4 \\
4 \\
3 \\
1\end{array}$ & $\begin{array}{l}0 \\
0 \\
0 \\
0 \\
0 \\
0 \\
0 \\
1 \\
0 \\
1 \\
0\end{array}$ & $\begin{array}{r}1 \\
1 \\
6 \\
12 \\
13 \\
14 \\
16 \\
7 \\
6 \\
6 \\
8\end{array}$ & $\begin{array}{l}0 \cdot 7 \\
0 \cdot 6 \\
3 \cdot 4 \\
5 \cdot 9 \\
5 \cdot 9 \\
5 \cdot 9 \\
6 \cdot 5 \\
2 \cdot 6 \\
2 \cdot 1 \\
2 \cdot 1 \\
2 \cdot 7\end{array}$ \\
\hline $\begin{array}{l}\text { Total } \\
\quad \text { Male } \\
\text { Female }\end{array}$ & $18^{25}$ & $13^{30}$ & $\begin{array}{l}0 \\
0 \\
0\end{array}$ & $4^{18}$ & $2^{2}$ & $28^{90}$ & 3.6 \\
\hline
\end{tabular}

*Incidence expressed as number of discharges/1000 Asian schoolchildren aged 5-16 years (figures supplied by the education authority).

TABLE II-Effect of unsupervised vitamin D supplementation on serum 25-OHD concentrations and incidence of biochemical and radiological evidence of rickets in 189 Asian children and adolescents (aged 5-17 years) in a single general practice from Fanuary to May 1979

\begin{tabular}{lccc}
\hline & $\begin{array}{c}\text { Mean } \pm \text { SEM } \\
\text { serum 25-OHD } \\
(\mathrm{nmol} / 1)\end{array}$ & \multicolumn{2}{c}{$\begin{array}{c}\text { No }(\%) \text { with } \\
\text { evidence of rickets }\end{array}$} \\
\cline { 3 - 4 } Stated supplement intake & & Biochemical* & Radiological \\
\hline Regular $(\mathrm{n}=57)$ & $20 \cdot 90 \pm 0 \cdot 76(\mathrm{n}=54) \dagger$ & $6(11)$ & $3(5)$ \\
Intermittent $(\mathrm{n}=53)$ & $17 \cdot 48 \pm 0 \cdot 71(\mathrm{n}=49) \dagger$ & $16(30)$ & $8(15)$ \\
None $(\mathrm{n}=79)$ & $16 \cdot 08 \pm 0 \cdot 57(\mathrm{n}=75) \dagger$ & $31(39)$ & $11(14)$
\end{tabular}

*Corrected serum calcium concentration less than $2.25 \mathrm{mmol} / 1(9 \mathrm{mg} / 100 \mathrm{ml})$; serum inorganic phosphorus less than normal range given by Round ${ }^{10}$ for age and sex; and serum alkaline phosphatase activity over 1). (Estimatiuns carried out using an SMA6 plus (norhnicon AutoAnalyz

Conversion: SI to traditional units-25-OHD: $1 \mathrm{nmol} / 1 \approx 0.4 \mathrm{ng} / \mathrm{ml}$.

\section{VITAMIN D DOSE-RESPONSE STUDIES}

During 1974-7 three studies were carried out in Asian subjects in Glasgow entailing the administration of foods fortified with vitamin $\mathrm{D}$ or the supervised administration of a vitamin $\mathrm{D}$ supplement. ${ }^{5-7}$ Serum concentrations of 25 -hydroxy vitamin D (25-OHD) were measured before and at the completion of each trial by competitive protein-binding assays carried out in the Middlesex Hospital, London (first study), ${ }^{8}$ and Stobhill Hospital, Glasgow (second and third studies). ${ }^{9}$ The assay in Glasgow was modified to include preparative chromatography. Duplicate estimations of serum 25-OHD concentrations using both methods gave good agreement $(r=0.91)$. Higher initial serum 25-OHD concentrations were found in the third trial, which we attribute to the exceptionally hot summer of 1976 .

The dose-response studies showed that no significant rise in serum 25-OHD concentrations occurred in Asian subjects whose daily vitamin $\mathrm{D}$ intake was increased by $5 \mu \mathrm{g}$ or less daily. In contrast, children whose vitamin $D$ intakes were increased by $10 \mu \mathrm{g}$ or more daily showed a satisfactory rise in serum $25-\mathrm{OHD}$ concentrations. The results of the three trials therefore indicated that a daily increment of $10 \mu \mathrm{g}$ of vitamin D would prevent Asian rickets.

\section{VALUE OF SELF-ADMINISTERED VITAMIN D SUPPLEMENTS}

In 1978 a campaign by school nurses and health visitors doubled the uptake of vitamin D supplements from a health board clinic serving the Asian population in the west of the city. Between January and May 1979 the success of this campaign was assessed by examining Asian mean age 11.5 years), or none (79 children, mean age 11.9 years); in addition a symptomatic inquiry was made, a history of hospital treatment for rickets obtained, and an examination for rachitic deformity carried out.

The survey showed that 16 children and adolescents $(8 \%$ of the sample) had received hospital treatment for rickets between 1970 and 1979 as inpatients or outpatients. Four children had required osteotomy, and the mothers of three families had been treated in hospital for severe osteomalacia.

The mean concentration of serum 25-OHD in children said to be taking a regular supplement was significantly higher $(t=1.96 ; \mathrm{df}=176$; $\mathrm{p}<0.05$; one-sided test) than that in children said to be taking a supplement intermittently or not at all (table II). The difference in mean concentrations between the groups taking a supplement intermittently and not at all was slight. Of the children taking the supplement regularly, $18(33 \%)$ had serum concentrations of $25-\mathrm{OHD}$ of under $12.5 \mathrm{nmol} / 1(5 \mathrm{ng} / \mathrm{ml})$, compared with $33(44 \%)$ of those not taking a supplement. This contrasts with the uniform rise in concentration produced by supervised administration of a supplement or by food fortification to the equivalent of about $10 \mu \mathrm{g}$ vitamin D daily (table III) and shows the difficulty in persuading many children to take a daily supplement when they feel well.

Despite the small rise in mean serum 25-OHD concentrations among the children whose regular supplement taking was unsupervised (table II), the incidence of biochemical and radiological abnormalities among these children was significantly lower than that in the children not taking a supplement $(z=4.27, p<0.01)$ or taking one only intermittently $(z=3 \cdot 18, p<0.01)$. In these last two groups the proportion of children with abnormalities was similar. The abnor-

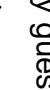

n


malities found in the children taking a regular supplement were mild, but six of the remaining children had severe biochemical and radiological evidence of rickets, which in two cases merited hospital admission. No children in the survey showed appreciable rachitic deformity.

\section{Preventive policy}

After the discovery of rickets and osteomalacia in the Glasgow Asian community in 1961 vitamin D supplements were made available to Asian schoolchildren at the discretion of school medical officers in the city. A film dealing with the problem was prepared by the health education unit, informal contacts were made with the leaders of the Asian community, and articles dealing with the problem appeared sporadically in the local press.

By 1977 it had become clear that these initiatives had proved inadequate. Admissions to hospital with severe rickets and osteomalacia were continuing and children with less severe forms of the disease were being seen by general practitioners. The issue of vitamin D supplements to older Asian children from the Greater Glasgow Health Board's central pharmacy was low. An average of only 225 $10-\mu \mathrm{g}$ doses of vitamin D was dispensed daily in 1976 and 1977 (fig 2). modest success of the small-scale campaign described above in increasing supplement uptake in the west of the city encouraged a further approach to the Greater Glasgow Health Board in 1978, which led to the setting up of a small multidisciplinary working group. This comprised a general administrator ( $\mathrm{Mr}$ W A Brown), nursing officer (Miss H T McIntosh), health education officer (Mr E B McMillan), dietitian (Mrs A Busby), pharmacist (Miss E M Meikle), community physician (RG), paediatrician (JAF), and physician (MGD). With the approval of the Board's policy and planning committee the working group devised the following preventive measures.

(1) Vitamin D supplements as drops, tablets, and a syrup were made available free of charge on demand to all vulnerable children who required them from birth until 18 years of age. This usually implied children of all ethnic groups up to 5 years of age and Asian children up to 18 years of age. The supplements were made available at all Health Board clinics and health centres and in three selected schools with a high proportion of Asian children. In practice, the drops were given to young children of all ethnic groups up to about 3 years of age and the tablets and syrup to older Asian children from about 3 to 18 years of age.

(2) A programme of in-service training was provided for community nurses, midwives, health visitors, dietitians, clinical medical officers, and general practitioners at a series of meetings in late 1978

TABLE III-Details of three trials ${ }^{5-7}$ in which foods fortified with vitamin $D$ or supervised supplements were given to 17 Asian adults and 121 children aged between 5 and 17 years

\begin{tabular}{|c|c|c|c|c|}
\hline \multirow{2}{*}{$\begin{array}{l}\text { Subjects in trial and amount of vitamin D given in fortified } \\
\text { food or as weekly supplement }\end{array}$} & \multirow{2}{*}{$\begin{array}{l}\text { Mean daily additional } \\
\text { vitamin D provided } \\
\text { ( } \mu \text { g ergocalciferol) }\end{array}$} & \multicolumn{3}{|c|}{ Mean \pm SEM serum 25-OHD (nmol/l) } \\
\hline & & Initial & $\mathrm{p}^{*}$ & Final \\
\hline
\end{tabular}

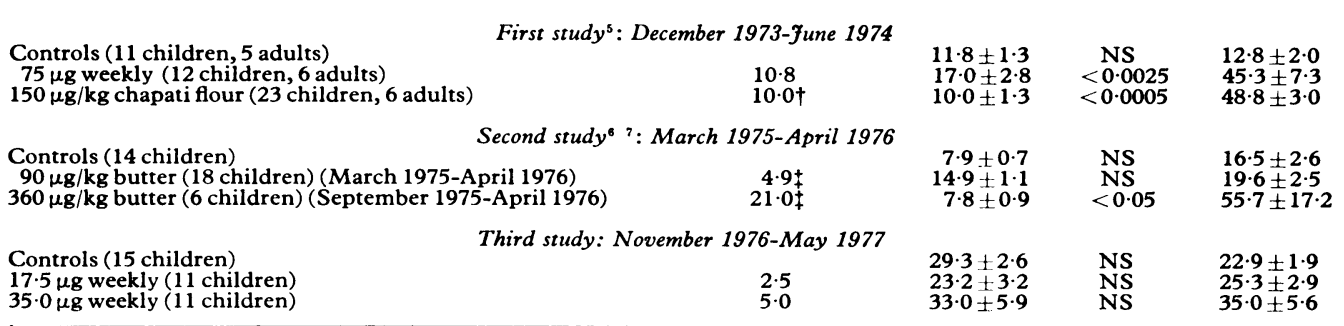

*Student's $t$ test.

Approximate value.

+Calculated from mean per caput consumption of fortified butter.
Conversion: SI to traditional units-25-OHD: $1 \mathrm{nmol} / 1 \approx 0.4 \mathrm{ng} / \mathrm{ml}$.

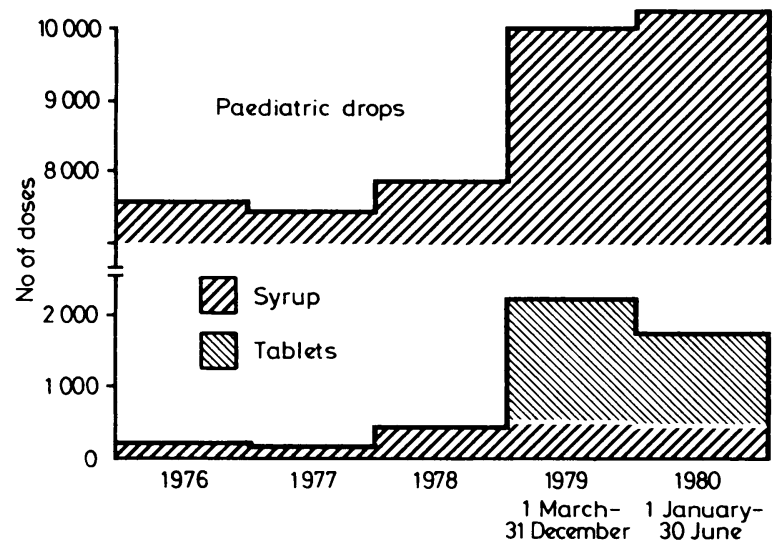

FIG $2-$ Number of $10-\mu \mathrm{g}$ doses of vitamin D dispensed from the central pharmacy, Greater Glasgow Health Board, between 1 January 1976 and 30 June 1980. The official rickets campaign began on 1 March 1979. The paediatric drops were given to children aged up to about 3 years in all ethnic groups; the syrup and tablets were given to Asian children aged about 3-18.

Thus only $8 \%$ of an Asian school population of about 2500 children in these years was potentially protected by vitamin $\mathrm{D}$ supplements from this source.

It seemed unlikely that our earlier proposals to fortify chapati flour with vitamin $\mathrm{D}$ would be accepted, ${ }^{5}$ and a further initiative based on a more effective policy of supplementation seemed essential. The and early 1979. Professional fact sheets explaining the Board's policy and the clinical features of Asian rickets were prepared by the health education unit and widely distributed. A simple fact sheet was distributed to the Asian community.

(3) The community relations council arranged a series of meetings on Asian rickets with leaders of the Asian community and further meetings with Asian social and religious groups were held during 1979.

(4) A 12-month programme of health education was begun by the health education unit directed at the Asian community and at schools with a high proportion of Asian pupils.

The campaign has now been operating for 20 months and several preliminary conclusions may be drawn. Awareness of Asian rickets has been greatly enhanced among Health Board personnel, school teachers, community relations staff, and, not least, the Asian community. Direct questioning suggests that most Asian schoolchildren in Glasgow now know something about the symptoms of rickets and its prevention. The campaign has also been monitored more objectively by measuring the demand for vitamin D supplements from the Board's central pharmacy, which supplies all Health Board clinics and health centres in the city (fig 2). The demand for supplements for older Asian children doubled in 1978 due to the informal campaign organised in the west of the city. From the beginning of March 1979, when the official campaign began, until the end of June 1980 the demand for supplements for older Asian children increased about eightfold over the low levels of 1975 and 1976 (delivery failures in March and April reduced the average number of tablets dispensed in 1980). The issue of paediatric drops to infants of all ethnic groups over this period increased by an average of 33\%. The cost of issuing free vitamin D supplements from 1 March to 31 December 1979 was estimated by the Greater Glasgow Health Board to be $£ .9700$. 


\section{Discussion}

Between 1968 and 1978 the probability of an Asian schoolchild being admitted to Glasgow hospitals with rickets was one in 29. A survey of one general practice in 1979 indicated that one Asian child in $12(8 \%)$ had been treated for rickets at city hospitals. One in seven (14\%) schoolchildren in the survey unprotected by vitamin $\mathrm{D}$ supplementation showed radiological evidence of active rickets and two out of five $(40 \%)$ biochemical evidence, while $44 \%$ had serum $25-\mathrm{OHD}$ concentrations of less than $12.5 \mathrm{nmol} / 1(5 \mathrm{ng} / \mathrm{ml})$. These results are similar to those found in our previous surveys in Glasgow in $1961^{1}$ and $1971^{2}$ and Bradford in $1973 .^{3}$

The above facts provided clear evidence of the failure of previous prophylactic measures and the need for a more effective campaign. The basis for such a campaign was provided by our three dose-response studies relating vitamin $\mathrm{D}$ intake to serum 25-OHD concentrations, which showed that supplements equivalent to $10 \mu \mathrm{g}$ vitamin $\mathrm{D}$ daily would provide effective prophylaxis. Successful prevention depends on making the supplements widely available and easily accessible. The pattern of serum 25-OHD concentrations in the children who were the subject of the small-scale campaign that preceded the Board's official campaign indicates that supplement taking in many children is at best intermittent. This study showed, however, that even intermittent consumption of supplements will reduce the prevalence and severity of Asian rickets, although being inferior to adequate food fortification as a prophylactic measure.

The key administrative decision in devising more effective preventive measures was the formation of a small multidisciplinary working group able to make clear recommendations to the Health Board. Health education officers and community dietitians who are often charged with responsibility for preventing problems such as Asian rickets may not be powerful enough or near enough to the decision-making process to implement effective policies by themselves. Asian community leaders, although willing to help, lack the expertise to implement preventive policies, which are the province of the community health services.

The ultimate success of the Glasgow rickets campaign remains to be evaluated, and the working group remains in being to monitor progress. In the interim, for an annual expenditure of about $£ 12000$ at 1979 prices, the campaign seems likely to reduce the prevalence of rickets in Asian children in Glasgow. Other health authorities faced with similar problems may find the Glasgow experience useful in planning their own preventive measures.

The serum 25-OHD assays carried out in Stobhill Hospital were made possible by a grant from the Medical Research Council. We are grateful to Dr M Perry, Sister M Finlay, and the health visitors and nurses of William Street Clinic, Anderston, Glasgow, whose preventive campaign provided a model for the working group. $\mathrm{Mr} \mathrm{W}$ Fife, community relations officer, also provided valuable help. We are indebted to Dr G D Forwell, chief area medical officer, Greater Glasgow Health Board, for his continuing support and encouragement.

Requests for reprints should be addressed to Dr M G Dunnigan, Stobhill General Hospital, Glasgow G21 3UW.

\section{References}

${ }^{1}$ Dunnigan MG, Paton JPJ, Haase S, McNicol GM, Gardner MD, Smith CM. Late rickets and osteomalacia in the Pakistani community in Glasgow. Scot Med f 1962;7:159-67.

${ }^{2}$ Ford JA, Colhoun EM, McIntosh WB, Dunnigan MG. Rickets and osteomalacia in the Glasgow Pakistani community, 1961-71. Br Med f 1972 ;ii:677-80.

${ }^{3}$ Ford JA, McIntosh WB, Butterfield R, et al. Clinical and sub-clinical vitamin D deficiency in Bradford children. Arch Dis Child 1976;51: 838-43.

4 Anonymous. Metabolic bone disease in Asians. Br Med f 1976;ii:442-3.

5 Pietrek J, Windo J, Preece MA, et al. Prevention of vitamin D deficiency in Asians. Lancet 1976;ii:1145-8.

${ }^{6}$ Dunnigan MG. Asian rickets and osteomalacia in Britain. In: Child nutrition and its relation to mental and physical development. Manchester: Kellogg Company of Great Britain, 1977:43-70.

${ }^{7}$ Dunnigan MG, Ford JA. Prevention of rickets and osteomalacia in Asians. Lancet 1977; ii:412-3.

${ }^{8}$ Preece MA, O'Riordan JLH, Lawsen DEM, Kodicek E. A competitive protein-binding assay for 25-hydroxycholecalciferol and 25-hydroxyergocalciferol in serum. Clin Chim Acta 1974;54:235-42.

9 Belsey RE, De Luca HC, Potts JT. A rapid assay for $25-\mathrm{OH}$ vitamin $\mathrm{D}_{3}$ without preparative chromatography. $₹$ Clin Endocrinol Metab 1974; 38:1046-51.

${ }^{10}$ Round JM. Plasma calcium, magnesium, phosphorus, and alkaline phosphatase levels in normal British schoolchildren. Br Med f 1973;iii: 137-40.

(Accepted 19 November 1980)

\section{SHORT REPORTS}

\section{Renal failure in tetanus}

Renal failure is not a recognised complication of tetanus. After the introduction of intermittent positive-pressure respirators, which prevent early death in many of the most severe cases of tetanus, the shock syndrome emerged as an important threat to survival. The syndrome appears to be due to tetanus intoxication of the sympathetic nervous system with attendant tachycardia ind wide fluctuations in blood pressure compromising tissue perfusion. ${ }^{1}$ In some patients blood pressure varies widely, and terminally patients may develop hypotension and a cold periphery. ${ }^{2} 3$

\section{Patients, methods, and results}

One hundred and six black patients with tetanus admitted to the respiratory unit over three years were studied to determine possible factors causing renal failure. All were initially given chlorpromazine. Fifty received intermittent positive-pressure respiration and were given diazepam $100 \mathrm{mg}$ four-hourly and alcuronium 10-20 mg intravenously when necessary. The incubation period was $9 \cdot 8 \pm \mathrm{SD} 4 \cdot 8$ days and the period of onset $38 \pm 22 \cdot 5$ hours. None of the patients had received tetanus toxoid or antitetanus serum.
Patients were divided into three groups. Those in group 1 had normal blood urea concentrations on admission and during the course of the illness; in group 2 urea concentrations were normal on admission but rose during the course of illness; and in group 3 urea concentrations were raised on admission. Blood volume, blood chemistry, central venous pressure, pulse rates, blood pressures, and blood and urine cultures were monitored in all patients. Sympathetic overactivity was diagnosed when labile blood pressures, pronounced tachycardia, and increased sweating were all noted.

Mortality in each group of patients

\begin{tabular}{cccc}
\hline Group & No of patients & No of deaths & Significance \\
\hline 1 & 83 & 15 & Group 1 v $2, \mathrm{p}<0.001$ \\
2 & 15 & 10 & Group 2 3 $\mathrm{p}>0.05$ \\
3 & $8^{*}$ & 5 & Group 1 v 3, p $<0.02$ \\
\hline
\end{tabular}

*Three patients were dehydrated.

The table shows the mortality in each group. Necropsy showed histological evidence of acute tubular necrosis in five patients. Sympathetic overactivity occurred in 28 of the 106 patients, of whom $19(68 \%)$ had renal failure. Hypotension was treated with $200 \mathrm{ml}$ of $4 \%$ salt-free human albumin, followed if necessary by dopamine or isoprenaline. 